\title{
LCN2 Gene
}

National Cancer Institute

\section{Source}

National Cancer Institute. LCN2 Gene. NCI Thesaurus. Code C71435.

This gene may play a role in both the transport of hydrophobic molecules and the mediation of inflammation. 